\title{
PERSPEKTIF PRODUK, HARGA, PROMOSI, DAN MEREK DALAM KEPUTUSAN PEMBELIAN SMARTPHONE SAMSUNG
}

\author{
Oleh: \\ Juhari \\ Dosen Sekolah Tinggi Ilmu Ekonomi Pertiba Pangkalpinang \\ Email:juharitz@gmail.com
}

\begin{abstract}
Abstrak
Smartphone Samsung mempunyai nilai penjualan tertinggi di pasar dunia dan termasuk di Indonesia. Perusahaan dapat memproduksi hasil yang relevan dengan minat dan kebutuhan konsumen. Penelitian ini bertujuan menguji pengaruh produk, harga, promosi dan merek terhadap keputusan konsumen untuk membeli Smartphone Samsung di Kota Pangkalpinang. Penelitian ini merupakan penelitian deskriptif kuantitatif dengan mengirimkan kuesioner kepada 100 responden dengan menggunakan teknik pengambilan sampling accidental. Teknik Analisis data yang digunakan adalah model analisis regresi linier berganda, uji koefisien determinasi $\left(\mathrm{R}^{2}\right)$, uji $\mathrm{F}$ (simultan) dan uji $\mathrm{t}$ (parsial). Berdasarkan kajian ini ditemukan bahwa variabel produk, harga, promosi dan merek berpengaruh signifikan terhadap keputusan konsumen untuk membeli Smartphone Samsung di Kota Pangkalpinang. Hal ini, dapat dilihat dari hasil perhitungan uji $\mathrm{F}$ bahwa $\mathrm{F}$ hitung $(11,063)>$ dari $F$ tabel (2.65) sedangkan signifikansi $(0.000)<\alpha 5 \%$ atau 0.05 , sehingga dapat diambil simpulan bahwa secara simultan produk, harga, promosi dan merek mempunyai hubungan yang signifikan terhadap keputusan pembelian konsumen Smartphone Samsung di Kota Pangkalpinang.

Kata Kunci: Produk, Harga, Promosi, Merek dan Keputusan Pembelian
\end{abstract}

\section{A. PENDAHULUAN}

Pada era teknologi informasi saat ini, perangkat telekomunikasi digital atau biasa disebut smartphone sudah menjadi basic needs bagi setiap orang. Terkait dengan fenomena ini, dipasaran gadget kini juga tersedia bermacam-macam merek gadget yang bersaing agar bisa menguasai pasar. Mulai dari tablet PC (Personal Computer) hingga sebuah smartphone, namun yang terpenting kini hampir semua perangkat mobile menawarkan fitur yang canggih untuk menunjang kebutuhan penggunanya. Secara umum, gadget memiliki kelengkapan yang unggul, apalagi ketika gadget sudah lengkap dengan perangkat lunak seperti android, windows phone ataupun $i O S$ (iPhone OS).

Banyaknya pilihan produk di pasaran gadget saat ini, sebenarnya sangat memudahkan konsumen karena alternatif yang tersedia sangat banyak. Apalagi kebanyakan produk perusahaan melakukan bentuk persuasif terhadap konsumen dengan iklan atau bauran promosi lainnya. Jadi, disinilah peran sebuah produk, 
harga, promosi dan merek sangat penting dalam hal mempengaruhi keputusan pembelian konsumen.

Dengan banyaknya produk yang disediakan oleh perusahaan, sehingga membuat konsumen semakin diuntungkan karena dapat memilih variasi produk yang lebih berkualitas tinggi. Maka dalam mendukung keputusan konsumen untuk pembelian produk yang sesuai dengan seleranya dengan produk berkualitas, harga yang cukup terjangkau, iklan yang intensif dilakukan serta merek yang ditawarkan memiliki nama dipasar smartphone. Akan tetapi ada banyak hal penting bagi produsen handphone dalam menjual produknya yaitu dengan mengetahui kebutuhan konsumen dan memahami selera dari pada konsumen.

Dari hal tersebut di atas, maka setiap produk menjadi lebih kompetitif, sehingga konsumen mempunyai banyak pilihan produk sebelum melakukan pembelian. Pengetahuan perusahaan berawal dari produk dan disesuaikan dengan harga. Setiap konsumen menginginkan banyak bentuk kemudahan misalnya diskon dan paket harga murah dari suatu barang. Melalui barang atau jasa yang ditawarkan tersebut, maka konsumen dapat menentukan minat beli terhadap barang atau jasa tersebut.

Selain itu, konsumen juga semakin teliti dalam mengambil keputusan pembelian dengan cara memperhatikan bentuk persuasif yang perusahaan smartphone lakukan. "Promosi merupakan faktor pendukung kesuksesan suatu program pemasaran. Walaupun suatu produk berkualitas baik, tetapi konsumen tersebut belum mengetahuinya bahwa produk itu tidak berguna, maka konsumen belum tentu mau membelinya (Tjiptono, 2008: 219).

Merek mempunyai peranan yang sangat penting, merek mencirikan suatu produk dengan produk pesaing, sehingga konsumen bisa membedakan merek mana yang miliki keunggulan. Merek (brand) bisa mempunyai peranan tersendiri bagi konsumen. Konsumen dapat tahu tentang suatu merek dari pengalaman konsumsinya terhadap suatu barang.

Samsung adalah salahsatu merek handphone dengan penjualan tertinggi di pasar dunia dan termasuk di Indonesia dengan penjualan 334,9 juta unit atau 24,5 $\%$ dari penjualan seluruh ponsel didunia pada kuartal I 2016 (www.detikinet.com, 2017). Smartphone Samsung kini menjadi trend bagi semua kalangan masyarakat di Indonesia. Pernyataan ini dapat dibuktikan berdasarkan data market share di Indonesia. Berdasarkan market share penjualan smartphone di Indonesia tahun 2017 dapat tertera pada tabel dibawah ini:

Tabel 1

Market Share Merek Smartphone Indonesia 2017

\begin{tabular}{clclc}
\hline Rangking & \multicolumn{1}{c}{ Merek 2016 } & Market Share & Merek 2015 & Market Share \\
\hline 1 & Samsung & $26 \%$ & Samsung & $24,8 \%$ \\
2 & Oppo & $19 \%$ & Asus & $15,9 \%$ \\
3 & Asus & $9 \%$ & Smartfren & $10.8 \%$ \\
4 & Advan & $8 \%$ & Advan & $9.6 \%$ \\
5 & Lain-Lainnya & $32 \%$ & Lain-Lainnya & $38,9 \%$ \\
\hline \multicolumn{2}{r}{ Sumber: Trendforce dan IDC (International Data Corporation), 2017 }
\end{tabular}


Dari tabel tersebut dapat dilihat bahwa penjualan handphone di Indonesia, smartphone Samsung merupakan smartphone mayoritas yang paling digemari oleh rakyat Indonesia dari tahun 2015 sampai dengan tahun 2016. Pada tahun 2015 penjualan smartphone di negara Indonesia dengan merek Samsung menepati peringkat pertama yaitu sebesar $24,8 \%$, disusul Asus menepati posisi kedua yaitu 15,9\%, dilanjuti Smartfren berada diposisi ketiga sebesar 10.8\% dan Advan diposisi ke empat sebesar 9,6\%. Sedangkan pada tahun 2016, Smartphone Samsung menepati peringkat pertama sebesar 26\%, Oppo menepati posisi kedua sebesar 19\%, Asus diposisi ketiga yaitu sebesar 9\% dan Advan diposisi keempat sebesar 8\%. Walaupun ada bermacam-macam merek smartphone lainnya dipasarkan di dalam negeri smartphone Samsung tetap menajadi pilihan konsumen pada saat ini.

Dari latar belakang tersebut, penulis menganggap penting untuk mebuat kajian judul: Keputusan Pembelian: Perspektif Produk, Harga, Promosi dan Merek Dalam Keputusan Pembelian Smartphone Samsung.

\section{B. KAJIAN PUSTAKA}

\section{Keputusan Pembelian}

Sebelum konsumen memutuskan pembelian terhadap produk, pada dasarnya adanya suatu kebutuhan yang berusaha dipenuhi. Proses pemenuhan kebutuhan berhubungan dengan beberapa alternatif sehingga perlu dilakukan evaluasi yang bertujuan untuk memperoleh alternatif terbaik dari persepsi konsumen.

Salusu (2007: 47) mendeskripsikan bahwa "pengambilan keputusan ialah proses untuk menentukan sikap dengan cara yang lebih efisien sesuai situasi". "Berdasarkan informasi mengenai kelebihan produk yang memotivasi orang untuk melakukan keputusan pembelian” (Tjiptono, 2012:156).

Amirullah (2002:62), menjelaskan "pengambilan keputusan konsumen adalah proses penggabungan pengetahuan dua atau lebih pilihan perilaku"."Pengambilan keputusan adalah proses menilai dan memilih alternatif sesuai dengan keinginan tertentu dengan menetapkan suatu pilihan yang dianggap paling menguntungkan" (Machfoedz, 2010:44).

Dari pengertian diatas dapat diberi ringkasan bahwa keputusan pembelian adalah sebagai proses menilai dan memilih berbagai alternatif sesuai kebutuhan dan kepentingan tertentu dengan memutuskan suatu pilihan yang dianggap paling baik dan memuaskan.

Menurut Kotler dan Armstrong (2012:179) mengemukakan proses pembelian tersebut melalui 5 (lima) tahapan, antara lain: (1)Pengenalan kebutuhan. (2) Pencarian informasi. (3) Evaluasi alternatif. (4)Keputusan pembelian. (5)Perilaku pasca pembelian.

\section{Faktor yang Berpengaruh terhadap Keputusan Pembelian}

Adapun hal-hal yang berpengaruh bagi konsumen dalam mengambil keputusan pembelian menurut Sutisna, (2012) seperti dibawah ini:

1. Konsumen individual. Artinya pembelian produk dengan merek tertentu dipengaruhi sikap konsumen secara individu. Pilihan individu didalam didalam pemilihan suatu produk dipengaruhi oleh selera, kebutuhan, persepsi 
terhadap karakteristik merek, kondisi demografis, life style dan karakteristik kepribadian individu.

2. Lingkungan yang mempengaruhi konsumen. Kondisi lingkungan sekitar juga berhubungan dengan pilihan-pilihan konsumen dalam menggunakan produk.

3. Strategi pemasaran. Semakin gencar strategi pemasaran yang diterapkan oleh perusahaan, maka sedikit banyak akan mempengaruhi keputusan konsumen dalam pembelian".

Menurut Andrew (2016) bahwa produk, harga, promosi dan tempat berpengaruh positif terhadap keputusan pembelian mobil di PT. Astra International Tbk Malalayang. Menurut Anuraga (2015) bahwa pengaruh produk, harga, promosi, dan merek signifikan terhadap keputusan pembelian ulang pada UD Galaras. Menurut Junio, dkk. (2013) bahwa harga, produk, promosi mempunyai pengaruh terhadap keputusan pembelian konsumen. Produk, harga dan promosi mempunyai hubungan positif terhadap keputusan pembelian mobil Buana Indomobil Trada Surabaya (Muanas, 2014).

\section{Produk}

Lamb Jr. et al, (2011: 414), menjelaskan "bahwa produk merupakan sebagai segala sesuatu, baik menguntungkan maupun tidak, yang didapatkan melalui pertukaran"."Produk adalah sesuatu yang ditawarkan ke pasar untuk diperlihatkan, dimiliki, digunakan, atau dikonsumsi sehingga dapat memuaskan keinginan atau kebutuhan manusia" (Kotler, 2013: 13).

"Produk merupakan sesuatu yang dapat disediakan kepasar untuk memperoleh perhatian, dibeli, digunakan, atau di konsumsi yang bisa memberi kepuasan terhadap keinginan dan kebutuhan konsumen" (Kotler dan Amstrong (2012:248)

Kotler dan Armstrong (2012: 346), menjelaskan "produk adalah segala suatu yang dapat ditawarkan kepasar untuk mendapatkan perhatian, dibeli, digunakan, atau dikonsumsi yang dapat memuaskan keinginan dan kebutuhan". "Produk adalah segala sesuatu yang dapat disediakan oleh perusahaan untuk diperhatikan, diminta, dicari, digunakan atau dikonsumsi untuk memenuhi kebutuhan dan keinginannya" (Tjiptono, 2008:96).

Dari definisi diatas dapat diringkas bahwa produk merupakan kumpulan atribut-atribut produk baik yang berwujud maupun tidak termasuk juga harga, kualitas, warna, desain, merek dan sebagainya.

Menurut Kasmir dan Jakfar (2007:107), strategi produk yang dilakukan perusahaan dalam mengembangkan produk sebagai berikut: (1) Menentukan logo dan motto. (2) Menciptakan merek. (3) Menciptakan kemasan. (4) Keputusan label.

\section{Harga}

Menurut Kasmir dan Jakfar, (2007:103) menjelaskan bahwa "harga adalah salah satu aspek penting dalam kegiatan marketing mix". "Harga merupakan nilai uang yang dibebankan atas suatu produk atau jasa, atau jumlah nilai yang ditukarkan para pelanggan untuk memperoleh utilitas dari mengkonsumsi suatu produk atau jasa tersebut" (Kotler dan Armstrong, 2012: 345). Menurut 
Ardiansyah (2015:232) bahwa penetapan harga dikaitkan dengan laba atau volume yang harus selaras dengan tujuan pemasaran yang dikembangkan dari tujuan perusahaan secara keseluruhan. Jadi, dapat dirincikan bahwa harga melekat pada produk berupa nilai yang dibayarkan konsumen atas penggunaan dari produk atau jasa untuk pemenuhan target perusahaan.

\section{Promosi}

Buchari (2009:135), mengemukakan bahwa "promosi adalah sejenis komunikasi yang memberi penjelasan yang meyakinkan calon konsumen tentang barang dan jasa". "Promosi adalah kegiatan perusahaan dalam rangka untuk menginfomasikan produknya kepada pasar sasarannya, aktivitas dari promosi yaitu iklan (advertising), penjualan pribadi (personal selling), hubungan masayarakat (public relation), promotion penjualan (sales promotion), serta pemasaran langsung (direct marketing)" (Kotler, 2013: 25).

Kotler dan Armstrong, (2012: 74) menjelaskan "bahwa promosi adalah aktifitas mengkomunikasikan keunggulan produk baru serta membujuk konsumen sasaran untuk membelinya". "Promosi adalah komunikasi pemasaran dengan tujuan mendorong permintaan, sedangkan komunikasi pemasaran adalah aktivitas pemasaran yang berusaha menginformasikan dan mempengaruhi calon konsumen sehingga dapat menerima, membeli dan memiliki loyalitas pada produk atau jasa yang diproduksi perusahaan yang bersangkutan" (Swastha dan Irawan, 2008:349). Menurut Isaac, dkk. (2015). Bauran promosi mempunyai keterkaitan terhadap keputusan konsumen didalam mengkonsumsi suatu produk.

Dari beberapa pengertian tersebut dapat diberi ringkasan bahwa promosi adalah komunikasi oleh pemasar dengan menginformasikan kepada calon pembeli mengenai sebuah produk untuk mempengaruhi suatu pendapat dan tanggapan konsumen.

\section{Merek}

Merek dapat dipakai sebagai alat untuk menciptakan pandangan tetentu dari para pembeli, baik melalui periklanan maupun melalui kegiatan persuasif lainnya. Peran merek bukan hal yang menjadi karakteristik khusus dari suatu produk, tapi bisa berwujud aset yang nilai ekonomis.

Kotler (2013: 332), menjelaskan bahwa "merek merupakan nama, istilah, tanda, simbol, atau rancangan atau kombinasi dari semua yang disebutkan untuk mendeskripsikan barang atau jasa". "Merek merupakan nama, istilah, lambang, desain, warna, gerak atau kombinasi produk lainnya sehingga dapat memberikan identitas dan diferensiasi terhadap produk" (Tjiptono, 2008: 105).

Sumarwan (2003:303) menjelaskan bahwa "merek adalah nama penting bagi produk atau jasa". "Merek merupakan janji penjual untuk secara konsisten memberikan tampilan, manfaat dan jasa tertentu pada pembeli" (Kotler, 2013:82).

Dari pengertian di atas dapat diberi kesimpulan bahwa merek merupakan sesuatu yang mempunyai peranan penting bagi konsumen didalam membuat keputusan pembelian dari pilihan suatu produk dan merek bisa memberi added value bagi suatu produk. 


\section{METODE PENELITIAN}

Berdasarkan deskripsi sebelumnya maka kerangka pemikiran penelitian dapat dipetakan seperti berikut ini:

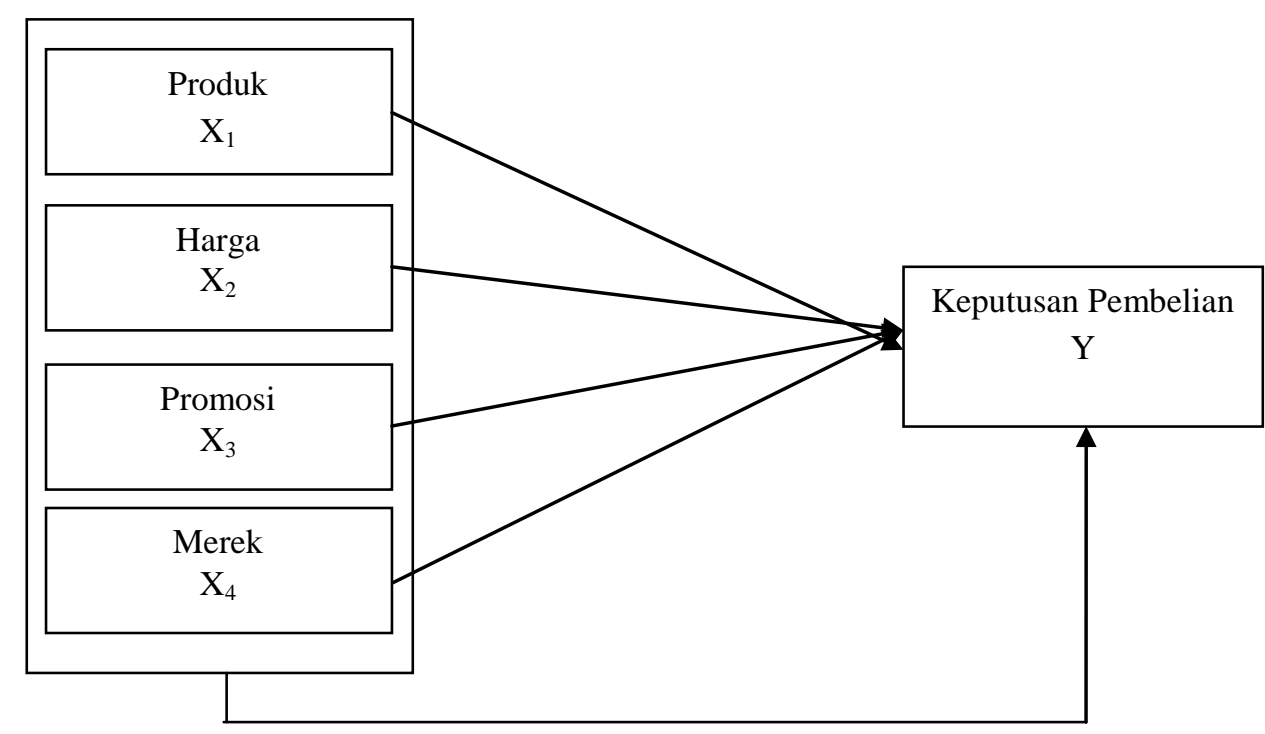

Gambar 1

Kerangka Pemikiran Penelitian

Populasi penelitian ini adalah pengguna Smartphone Samsung di Kota Pangkalpinang. Populasinya tersebar dibeberapa Kecamatan dan jumlahnya tidak diketahui secara pasti. Teknik pengambilan sampel adalah dengan menggunakan sampling accindental yakni teknik penentuan sampel berdasarkan kebetulan, yaitu konsumen Smartphone Samsung yang secara kebetulan dijumpai peneliti untuk dijadikan sampel. Karena jumlah populasinya yang tidak bisa dihitung dengan pasti, didalam perhitungan sampel, peneliti menggunakan rumus Paul Leedy yang mengatakan bahwa ukuran sampel adalah:

Keterangan:

$$
n=\left(\frac{Z}{e}\right)^{2}(P)(1-p)
$$

$\begin{array}{ll}\mathrm{n} & : \text { Ukuran sampel } \\ \mathrm{z} & : \text { Standar score untuk } \alpha \text { yang dipilih } \\ e & : \text { Sampling error } \\ \mathrm{p} & \text { : Proposi yang diestimasi suatu atribut yang ada dalam suatu } \\ & \text { populasi }\end{array}$

Maka:

$$
\begin{aligned}
n & =\left(\frac{Z}{e}\right)^{2}(P)(1-p) \\
n & =\left(\frac{1,96}{0,01}\right)^{2}(0,5)(1-0,5) \\
n & =96,04 \text { dibulatkan } 100
\end{aligned}
$$


Penelitian ini diambil 100 responden dari keseluruhan jumlah konsumen yang memakai Smartphone Samsung di Kota Pangkalpinang. Variabel dalam penelitian ini memakai independent variable yang terdiri dari: produk, harga, promosi dan merek serta variabel terikat atau dependent variable yakni keputusan pembelian. Metode pengumpulan data dalam penelitian ini dilaksanakan dengan membagikan kuesioner kepada responden yang menggunakan Smartphone Samsung sebanyak 100 responden. Teknik analisis data penelitian ini adalah dengan analisis statistik deskriptif, analisis regresi berganda, korelasi (r) dan koefisien determinasi.

\section{HASIL DAN PEMBAHASAN}

Uji validitas menjelaskan sejauhmana suatu instrumen penelitian menggunakan apa yang ingin di ukur yang di gunakan adalah perorangan dengan level signifikan 5\%. Syarat minimum untuk dianggap suatu butir instrumen valid adalah nilai indeks validitasnya memiliki nilai $r$ hitung lebih dari 0.202 .

Tabel 2

Hasil Uji Validitas

\begin{tabular}{|c|c|c|c|c|}
\hline Variabel & Item & r hitung & $r$ tabel & Keterangan \\
\hline \multirow{7}{*}{ Produk } & X1.1 & 0,476 & 0.202 & Valid \\
\hline & $\mathrm{X} 1.2$ & 0,567 & 0.202 & Valid \\
\hline & X1.3 & 0,498 & 0.202 & Valid \\
\hline & X1.4 & 0,470 & 0.202 & Valid \\
\hline & X1.5 & 0,560 & 0.202 & Valid \\
\hline & X1.6 & 0,625 & 0.202 & Valid \\
\hline & $\mathrm{X} 2.1$ & 0,470 & 0.202 & Valid \\
\hline \multirow{4}{*}{ Harga } & $\mathrm{X} 2.2$ & 0,494 & 0.202 & Valid \\
\hline & $\mathrm{X} 2.3$ & 0,454 & 0.202 & Valid \\
\hline & $\mathrm{X} 2.4$ & 0,549 & 0.202 & Valid \\
\hline & $\mathrm{X} 2.5$ & 0,395 & 0.202 & Valid \\
\hline \multirow{7}{*}{ Promosi } & X3.1 & 0,555 & 0.202 & Valid \\
\hline & X 3.2 & 0,609 & 0.202 & Valid \\
\hline & X3.3 & 0,589 & 0.202 & Valid \\
\hline & X 3.4 & 0,402 & 0.202 & Valid \\
\hline & X3.5 & 0,349 & 0.202 & Valid \\
\hline & X3.6 & 0,471 & 0.202 & Valid \\
\hline & $\mathrm{X} 4.1$ & 0,311 & 0.202 & Valid \\
\hline \multirow{7}{*}{ Merek } & $\mathrm{X} 4.2$ & 0,385 & 0.202 & Valid \\
\hline & $\mathrm{X} 4.3$ & 0,437 & 0.202 & Valid \\
\hline & $\mathrm{X} 4.4$ & 0,427 & 0.202 & Valid \\
\hline & $\mathrm{X} 4.5$ & 0,347 & 0.202 & Valid \\
\hline & $\mathrm{X} 4.6$ & 0,372 & 0.202 & Valid \\
\hline & $\mathrm{X} 4.7$ & 0,219 & 0.202 & Valid \\
\hline & $\mathrm{X} 4.8$ & 0,322 & 0.202 & Valid \\
\hline \multirow{6}{*}{ Keputusan Pembelian } & Y1.1 & 0,741 & 0.202 & Valid \\
\hline & Y1.2 & 0,788 & 0.202 & Valid \\
\hline & Y1.3 & 0,792 & 0.202 & Valid \\
\hline & Y1.4 & 0,600 & 0.202 & Valid \\
\hline & Y1.5 & 0,587 & 0.202 & Valid \\
\hline & Y1.6 & 0,747 & 0.202 & Valid \\
\hline
\end{tabular}

Sumber: Diolah dari data primer, 2017 
Berdasarkan hasil uji validitas pada tabulasi di atas setiap butir pertanyaan variabel produk, harga, promosi, merek dan keputusan pembelian mempunyai nilai $r$ hitung $>r$ tabel. Sehingga, semua item pertanyaan setiap variabel tersebut valid bisa di analisis lebih lanjut.

Reliabilitas menunjukkan bahwa jika instrumen disebutkan reliabel bila dapat dipakai lebih dari satu kali dalam dimensi waktu yang berbeda, namun dapat menunjukkan hasil yang konsisten atau instrumen yang terukur dan handal. Nilai r dianggap reliabel yaitu 0,60 (cukup tinggi). Hasil dapat dilihat pada tabel berikut ini:

Tabel 3

Hasil Uji Reliabilitas

\begin{tabular}{|c|c|c|}
\hline Variabel & Alpa & Keterangan \\
\hline Produk & 0,750 & Reliabel \\
\hline Harga & 0,728 & Reliabel \\
\hline Promosi & 0,735 & Reliabel \\
\hline Merek & 0,677 & Reliabel \\
\hline Keputusan Pembelian & 0,790 & Reliabel \\
\hline
\end{tabular}

Sumber: Diolah dari data primer, 2017

Pada Tabel diatas dimana hasil uji reliabilitas tersebut menyatakan semua variabel memiliki koefisien Alpha yang cukup besar yaitu >0,60 sehingga bisa dinyatakan semua item pernyataan dari setiap variabel dinyatakan reliabel yang artinya bahwa kuesioner dalam penelitian ini merupakan kuesioner yang handal dan layak untuk dianalisis berikutnya.

\section{Uji Asumsi Klasik}

a. Uji Normalitas

Model regresi dikatakan baik apabila memiliki distribusi normal atau mendekati normal. Suatu data dapat terdistribusi normal dengan melihat grafik normal probability plot dengan mengkomparasikan distribusi kumulatif dari data yang sesungguhnya dengan distribusi kumulatif dari data distribusi normal. Jika distribusi normal, maka garis sebaran data akan mengikuti garis diagonalnya.

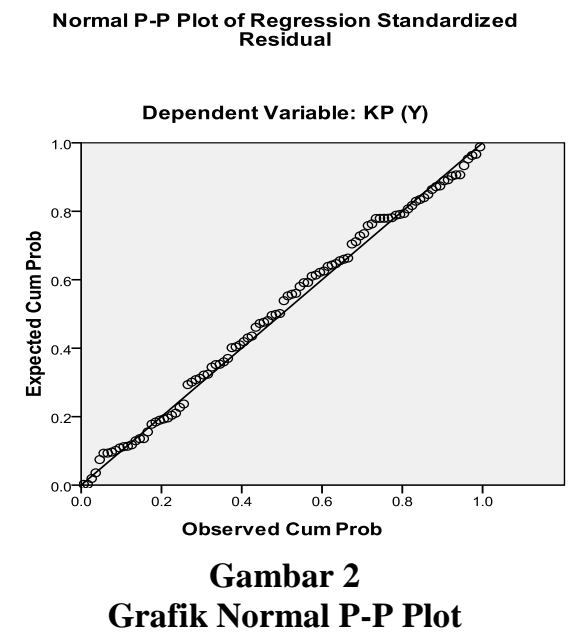


Berdasarkan hasil uji asumsi klasik yaitu uji normalitas data, uji multikolinearitas dan uji heteroskedastisitas yang peneliti lakukan bahwa model penelitian ini sudah memenuhi syarat dan lulus untuk di analisis dengan model regresi berganda dalam penelitian ini.

Dari gambar grafik di atas bisa dikatakan normal p-p plot berada disekitar garis diagonal dan model regresi sangat akurat digunakan dan mencapai asumsi normalitas data.

\section{b. Hasil Uji Multikolinieritas}

Pengujian multikolinearitas bertujuan untuk melihat tingkat signifikansi korelasi yang mendekati sempurna antar variabel independen. Jika variabel bebas satu dengan variabel bebas yang lain terdapat korelasi yang signifikan, maka pada model regresi linear tersebut terdapat gejala multikolinearitas. Tabel dibawah menyajikan hasil pengujian multikolinearitas:

Tabel 4

Hasil Uji Multikolinieritas

\begin{tabular}{|c|c|c|}
\hline \multirow{2}{*}{ Keterangan } & \multicolumn{2}{|c|}{ Collinearity Statistics } \\
\hline & Tolerance & VIF \\
\hline Produk & 0,504 & 1,985 \\
\hline Harga & 0,310 & 3,224 \\
\hline Promosi & 0,310 & 3,228 \\
\hline Merek & 0,513 & 1,948 \\
\hline
\end{tabular}

Sumber: Diolah dari data primer, 2017

Berdasarkan hasil pengujian multikolinieritas, bahwa nilai tolerance variabel independen $<0.10$ yang artinya tidak terdapat korelasi antara variabel independen yang lebih dari 95\%. Demikian juga dengan nilai VIF (Variance Inflation Factor), dari kedua variabel bebas yang diuji tidak ada nilai VIF yang lebih besar (>) dari 10, maka dapat dikonklusikan tidak terjadi multikolinieritas antar independent variable dalam persamaan regresi.

\section{c. Uji Heteroskedastisitas}

Uji asumsi klasik, dimana variance dari residual yang dihasilkan adalah homokedastisitas, yaitu terjadi kemiripan variance dari residual satu dengan yang lainnya. Melihat ada atau tidaknya heteroskedastisitas dapat dilaksanakan dengan memperhatikan pola tertentu titik plot (menyebar atau menyempit dan bergelombang) pada grafik plot (scatterplot) antara nilai perkiraan variabel terkait (ZPRED) yaitu dengan residualnya (SRESID). 
Scatterplot

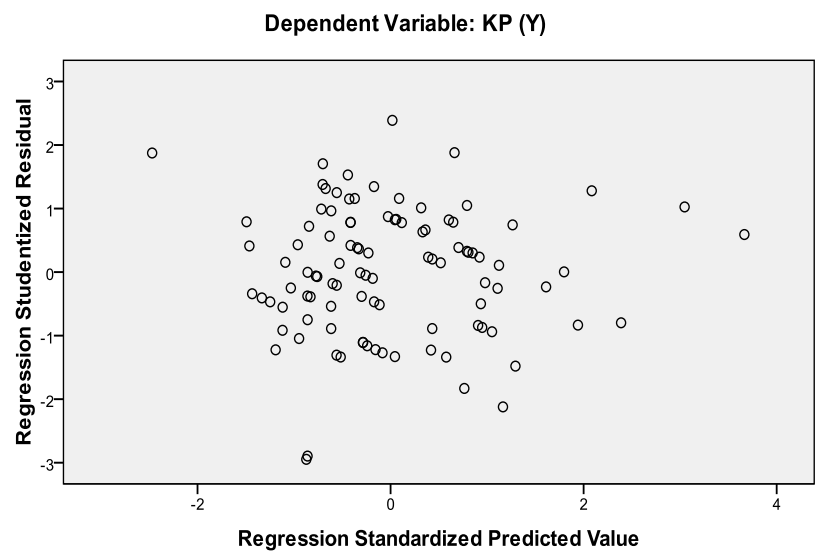

Gambar 3

Scatterplot

Hasil grafik Scatterplot yang tersaji diatas memperlihatkan bahwa titik-titik menyebar diatas maupun dibawah angka 0 dan tersebar secara acak pada sumbu Y, serta tidak mempunyai pola yang jelas atau tidak membentuk suatu pola. Untuk itu bisa dijelaskan tidak terjadi heteroskedastisitas pada model persamaan regresi, sehingga persamaan regresi akurat dipakai sebagai model analisis.

\section{Analisis Regresi Linier Regresi Berganda}

Penelitian ini dianalisis dengan regresi berganda untuk pembuktian hipotesis penelitian. Analisis ini diolah dari data input jawaban dalam kuesioner. Perhitungan analisis regresi berganda dalam penelitian ini dengan menggunakan bantuan program SPSS for Windows versi 17 yang dirincikan berikut ini:

Tabel 5

Hasil Analisis Regresi Linier Berganda

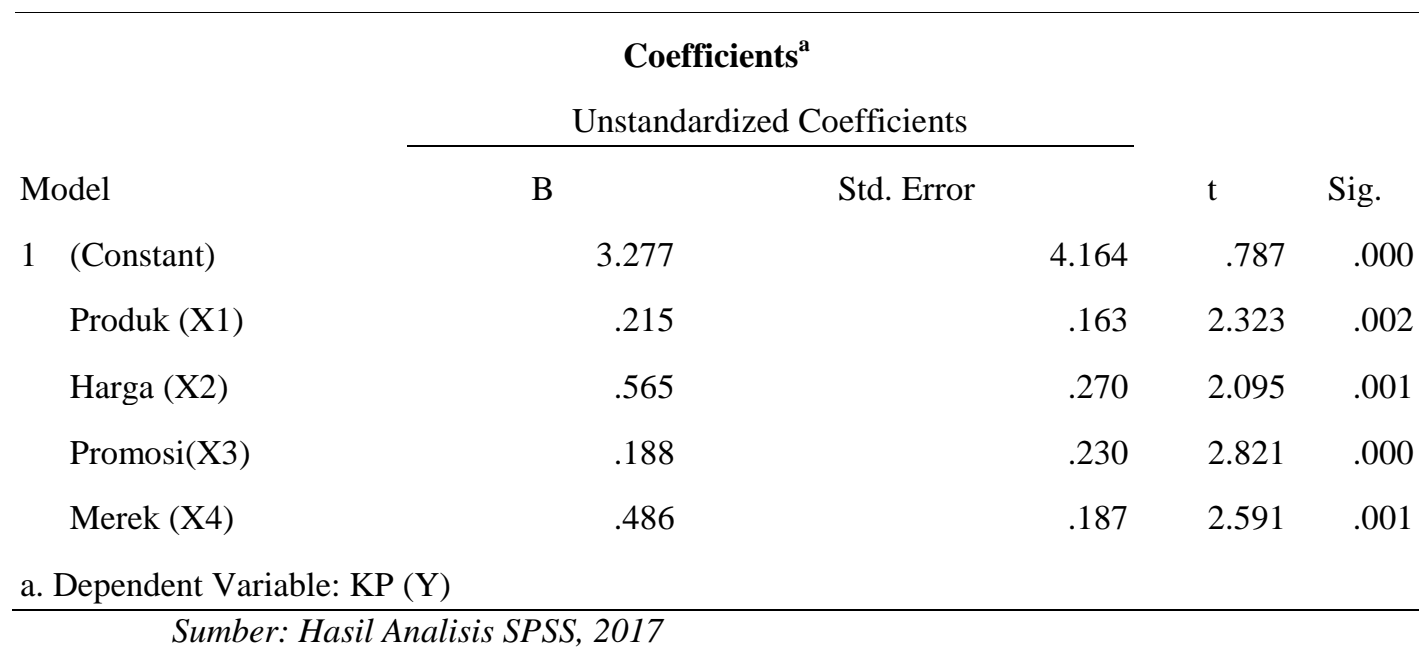


Berdasarkan data Tabel 5 dimana hasil analisis regresi diperoleh persamaan regresi sebagai berikut:

$$
Y=3,277+0,215 X_{1}+0,565 X_{2}+0,188 X_{3}+0,486 X_{4}
$$

Dari persamaan regresi berganda di atas variabel produk $\left(\mathrm{X}_{1}\right)$, harga $\left(\mathrm{X}_{2}\right)$, promosi $\left(\mathrm{X}_{3}\right)$ dan merek $\left(\mathrm{X}_{4}\right)$, mempunyai nilai positif yang artinya semua variabel tersebut berpengaruh secara signifikan terhadap keputusan pembelian (Y) konsumen Smartphone Samsung di Kota Pangkalpinang sehingga apabila variabelvariabel bebas tersebut mengalami kenaikan maka nilai variabel terikat juga akan mengalami kenaikan dan sebaliknya serta lebih rinci dapat dijelaskan sebagai berikut:

a. Konstanta 3,277

b. Nilai konstanta sebesar 3, 277 menunjukkan bahwa jika nilai variabel produk, harga, promosi dan merek sama dengan nol maka, keputusan pembelian konsumen Smartphone Samsung di Kota Pangkalpinang adalah 3, 277

c. $\mathrm{b}_{1}=0,215$

Berarti variabel produk mempengaruhi keputusan pembelian konsumen Smartphone Samsung di Kota Pangkalpinang secara positif yang artinya jika produk meningkat sebesar $1 \%$ maka keputusan pembelian konsumen Smartphone Samsung akan meningkat sebesar 0,215\%. Sebaliknya jika produk menurun sebesar $1 \%$ maka keputusan pembelian akan menurun sebesar $0,215 \%$.

d. $\quad b_{2}=0.565$

Berarti variabel harga mempengaruhi keputusan pembelian konsumen Smartphone Samsung di Kota Pangkalpinang secara positif yang artinya jika harga meningkat sebesar 1\% maka keputusan pembelian konsumen Smartphone Samsung akan meningkat sebesar $0,565 \%$. Sebaliknya jika harga menurun sebesar $1 \%$ maka keputusan pembelian akan menurun sebesar $0,565 \%$.

e. $b_{3}=0.188$

Berarti variabel promosi mempengaruhi keputusan pembelian konsumen Smartphone Samsung di Kota Pangkalpinang secara positif yang artinya jika promosi meningkat sebesar $1 \%$ maka keputusan pembelian konsumen Smartphone Samsung akan meningkat sebesar 0,188\%. Sebaliknya jika promosi menurun sebesar $1 \%$ maka keputusan pembelian akan menurun sebesar $0,188 \%$.

f. $\quad b_{4}=0.486$

Berarti variabel merek mempengaruhi keputusan pembelian konsumen Smartphone Samsung di Kota Pangkalpinang secara positif yang artinya jika merek meningkat sebesar $1 \%$ maka keputusan pembelian konsumen Smartphone Samsung akan meningkat sebesar 0,486\%. Sebaliknya jika merek menurun sebesar $1 \%$ maka keputusan pembelian akan menurun sebesar $0,486 \%$. 
Tabel 6

Koefisien Korelasi dan Koefisien Determinasi

\begin{tabular}{|c|c|c|c|c|}
\hline \multicolumn{5}{|c|}{ Model Summary ${ }^{b}$} \\
\hline Model & $\mathrm{R}$ & R Square & $\begin{array}{l}\text { Adjusted R } \\
\text { Square }\end{array}$ & $\begin{array}{l}\text { Std. Error of the } \\
\text { Estimate }\end{array}$ \\
\hline 1 & $.564^{\mathrm{a}}$ & .318 & .289 & 2.805 \\
\hline
\end{tabular}

a. Predictors: (Constant), Merek (X4), Produk (X1), Harga (X2),

Promosi(X3)

b. Dependent Variable: KP (Y)

Sumber : Hasil analisis SPSS, 2017

Dilihat dari Tabel 6 koefisien determinasi $\left(\mathrm{R}^{2}\right)$ menunjukkan angka $R$ Square 0,318 atau $31,8 \%$ yang berarti variasi variabel keputusan pembelian konsumen Smartphone Samsung dideskripsikan oleh variabel produk, harga, promosi dan merek serta sisanya dapat dideskripsikan oleh variabel lainnya yang tidak masuk dalam penelitian ini.

\section{Pengujian Hipotesis}

\section{Uji F}

Uji F dimanfaatkan untuk melihat semua variabel produk, harga, promosi dan merek berpengaruh secara bersama terhadap keputusan pembelian konsumen Smartphone Samsung di Kota Pangkalpinang. Hasil uji F seperti berikut ini :

\section{Tabel 7}

\section{Uji F}

ANOVA $^{\text {b }}$

\begin{tabular}{|ll|r|r|r|r|r|}
\hline Model & & Sum of Squares & df & Mean Square & F & Sig. \\
\hline 1 & Regression & 348.160 & 4 & 87.040 & 11.063 & $.000^{\mathrm{a}}$ \\
& Residual & 747.400 & 95 & 7.867 & & \\
& Total & 1095.560 & 99 & & & \\
\hline
\end{tabular}

a. Predictors: (Constant), Merek (X4), Produk (X1), Harga (X2), Promosi(X3)

b. Dependent Variable: KP (Y)

Sumber: Hasil analisis SPSS, 2017

Berdasarkan data dari Tabel 7 hasil perhitungan uji F, dapat dilihat bahwa $\mathrm{F}_{\text {hitung }} 11,063$ dan $\mathrm{F}_{\text {tabel }}$ dengan $\mathrm{df}_{1}=$ derajat pembilangan 4 dan $\mathrm{df}_{2}=$ derajat penyebut 100 dengan taraf 5\% maka didapat $F_{\text {tabel }} 2.65$ berarti $F_{\text {hitung }}>F_{\text {tabel }}$. Dan nilai $p=0,000<0,05$, sehingga Ho ditolak dan Ha diterima berarti variabel produk, harga, promosi dan merek secara bersamaan atau simultan mempengaruhi variabel keputusan pembelian Smartphone Samsung di Kota Pangkalpinang 
Provinsi Kepulauan Bangka Belitung.

Uji t

Uji t dimanfaatkan untuk melihat besarnya pengaruh variabel bebas secara parsial dalam menjelaskan variasi variabel terikat. Hasil analisis uji t sebagai berikut:

Tabel 8

T Hitung

\begin{tabular}{|c|c|c|}
\hline Model & $\mathbf{t}$ & Sig. \\
\hline Produk & 2.323 & .002 \\
\hline Harga & 2.095 & .001 \\
\hline Promosi & 2.821 & .000 \\
\hline Merek & 2.591 & .001 \\
\hline
\end{tabular}

Sumber: Hasil analisis SPSS, 2017

Hasil Coefficient melalui pengujian hipotesis dan kemudian dibandingkan dengan $\mathrm{t}$ tabel yaitu $\mathrm{n}=$ jumlah sempel 100 dengan $\alpha=0.05$ maka didapat $\mathrm{t}$ tabel sebesar 1.9732. Jadi hasil dari tiap-tiap variabel dapat diketahui variabel yang mempunyai pengaruh dengan keputusan pembelian sebagai berikut:

H1 : Uji hipotesis produk terhadap keputusan pembelian

Dari hasil perhitungan yang diperoleh $\mathrm{t}$ hitung untuk $\mathrm{X}_{1}$ sebesar 2.323 lebih besar dari t tabel 1.9732 dan dengan signifikansi sebesar 0,002 lebih kecil dari taraf signifikansi 0.05 . Berarti $\mathrm{H} 1$ diterima dan Ho ditolak, maka ini menunjukkan variabel produk memiliki pengaruh positif dan signifikan terhadap keputusan pembelian Smartphone Samsung di Kota Pangkalpinang.

$\mathrm{H} 2$ : Uji hipotesis harga terhadap keputusan pembelian

Dari hasil perhitungan yang diperoleh $\mathrm{t}$ hitung untuk $\mathrm{X}_{2}$ sebesar 2,095 lebih besar dari t tabel 1.9732 dan dengan signifikansi sebesar 0.001 lebih kecil dari taraf signifikansi 0.05 . Berarti $\mathrm{H} 2$ diterima dan Ho ditolak, maka ini menunjukkan variabel harga memiliki pengaruh positif dan signifikan terhadap keputusan pembelian Smartphone Samsung di Kota Pangkalpinang.

H3 : Uji hipotesis promosi terhadap keputusan pembelian

Dari hasil perhitungan yang diperoleh t hitung untuk $\mathrm{X}_{3}$ sebesar 2.821 lebih besar dari t tabel 1.9732 dan dengan signifikansi sebesar 0.000 lebih kecil dari taraf signifikansi 0.05. Berarti H3 diterima dan Ho ditolak, maka ini menunjukkan variabel promosi memiliki pengaruh positif dan signifikan terhadap keputusan pembelian Smartphone Samsung di Kota Pangkalpinang.

H4 : Uji hipotesis merek terhadap keputusan pembelian

Dari hasil perhitungan yang diperoleh $\mathrm{t}$ hitung untuk $\mathrm{X}_{4}$ sebesar 2,591 lebih besar dari t tabel 1.9732 dan dengan signifikansi sebesar 0.001 lebih kecil dari taraf signifikansi 0.05 . Berarti $\mathrm{H} 4$ diterima dan Ho ditolak, maka ini menunjukkan variabel merek memiliki pengaruh positif dan signifikan terhadap keputusan pembelian Smartphone Samsung di Kota Pangkalpinang. 


\section{E. SIMPULAN}

Berdasarkan analisis regresi berganda didapatkan persamaan: $\mathrm{Y}=3,277+$ $0,215 \mathrm{X}_{1}+0,565 \mathrm{X}_{2}+0,188 \mathrm{X}_{3}+0,486 \mathrm{X}_{4}$ yang artinya bahwa terdapat pengaruh yang positif dan signifikan antara variabel produk $\left(X_{1}\right)$, harga $\left(X_{2}\right)$, promosi $\left(\mathrm{X}_{3}\right)$ dan merek $\left(\mathrm{X}_{4}\right)$ secara simultan terhadap keputusan pembelian Smarphone Samsung di Kota Pangkalpinang Provinsi Kepulauan Bangka Belitung. Berdasarkan koefisien determinasi $\left(\mathrm{R}^{2}\right)$ menunjukkan angka $R$ Square 0,318 atau $31,8 \%$ yang berarti variasi variabel keputusan pembelian konsumen Smartphone samsung di Kota Pangkalpinang dapat diterangkan oleh variabel produk, harga, promosi dan merek serta sisanya dapat diterangkan oleh variabel lainnya yang tidak masuk dalam model penelitian ini.

\section{DAFTAR PUSTAKA}

Amirullah. (2002). Perilaku Konsumen. Yogyakarta: Graha Ilmu.

Andrew, M. (2016). Pengaruh Produk, Harga, Promosi dan Tempat Terhadap Keputusan Pembelian Mobil Di PT. Astra International Malalayang. Jurnal EMBA, Volume 04, 472-483.

Anuraga, W. (2015). Pengaruh Produk, Harga, Promosi, dan Merek Terhadap Keputusan Pembelian Ulang Pada UD Galarasa STIESIA Surabaya. Jurnal Imu dan Riset Manajemen, Volume 4, 1-18.

Ardiansyah, T. (2015). Pengaruh Bauran Pemasaran Terhadap Keputusan Konsumen Dalam Membeli Produk Modem CDMA EDVO Smart Telecom. Jurnal JABE, Volume 01, 228-240.

Buchari, Alma. (2009). Manajemen Pemasaran dan Pemasaran Jasa. Bandung: Graha Ilmu.

Fandy, T. (2008). Pemasaran Strategi. Yogyakarta: CV.Andi Offset.

Isaac, O. (2015). The Influence of Brand Image and Promotional Mix on Consumer Buying Decision-A Study of Beverage Consumers In Lagos State, Nigeria. British Journal of Marketing Studies, Volume 03, 115129.

Junio, A. (2013). The Analysis of Product, Price, Place, Promotion and Service Quality on Customers' Buying Decision of Convenience Store: A Survey of Young Adult In Bekasi, West Java, Indonesia. International Journal of Advances in Mangement and Economics, Volume 03, 97-109.

Kasmir, J. (2007). Manajemen Pemasaran. Jakarta: Erlangga. 
Kotler Philip, A. (2012). Prinsip-Prinsip Pemasaran. Jakarta: Erlangga.

Kotler, P. (2013). Manajemen Pemasaran (Edisi Millenium ed.). Jakarta: PT Prenhalilindo.

Lamb William, J. F. (2011). Pemasaran (Edisi Pertama ed.). Jakarta: Salemba Empat.

Machfoedz, M. (2010). Pengantar Pemasaran Modern. Yogyakarta: Akademi Manajemen YKPN.

Muanas, A. (2014). Pengaruh Produk,Harga dan Promosi Terhadap Keputusan Pembelian Mobil Buana Indomobil Trada. Jurnal Ilmu dan Riset Manajemen, Volume 03, 141-153.

Salusu, I. (2007). Pengambilan Keputusan Strategik untuk Organisasi Publik dan Organisasi non Profit. Jakarta: PT. Grasindo.

Sumarwan, U. (20013). Perilaku Konsumen. Bogor: Ghalia Indonesia.

Sutisna. (2012). Perilaku Konsumen dan Komunikasi Pemasaran. Bandung: Rosda Karya.

Swastha Basu, I. (2008). Manajemen Pemasaran Modern. Yogyakarta: Liberty.

Tjiptono Fandy, G. C. (2012). Pemasaran Strategi. Yogyakarta: CV. Andi Offset.

Tjiptono, F. (2008). Pemasaran Strategi. Yogyakarta: CV. Andi Offset. 